\title{
State of the Propulsive-Group Development for Enhanced Anti- Armored Guided Missile
}

\author{
Goran Marjanović1 \\ Stevan Kozomara ${ }^{1)}$ \\ Srđan Stojković ${ }^{1)}$ \\ Nikola Gligorijević ${ }^{1)}$ \\ Saša Živković ${ }^{1)}$ \\ Bojan Pavković ${ }^{1)}$
}

\begin{abstract}
The main propulsive group of anti-armor guided missile is reinforced by additional propulsive group with the aim to increase the range. Final concept of the propulsion has been adopted after consideration of several proposed solutions. Two additional motors are made and they are currently under development. The first results were obtained, and the additional motors at this stage are refined through the static tests as well as through the correction of the composition and the design of the propellant grains. An overview of the common procedure is described on the way to winning the final solution for rocket propulsion
\end{abstract}

Key words: anti-armor rocket, rocket motor, propulsive group, starting (booster) motor, marching (sustainer) motor, propellant grain, thrust, pressure, range.

\section{Introduction}

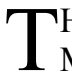
HE basic version of the Russian antitank guided missile Maljutka (Fig.1) has been in the armament of our army since the seventies of the last century.

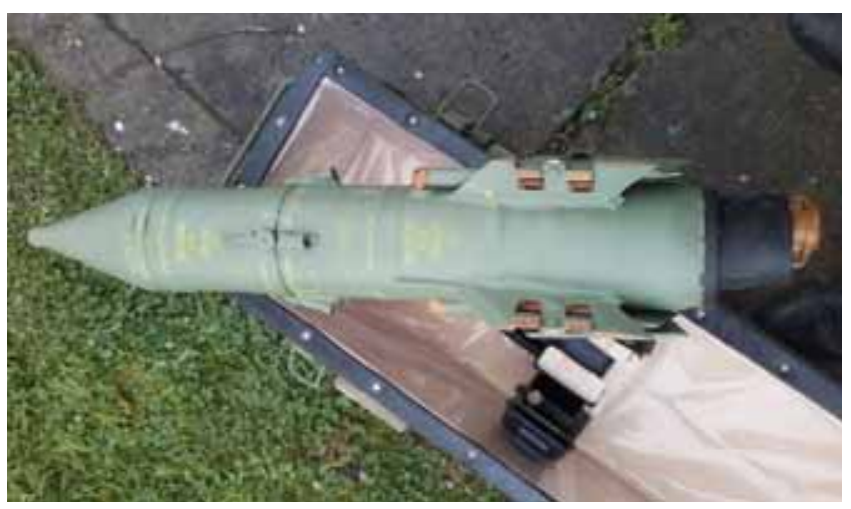

Figure 1. The rocket Maljutka

The license was bought from the USSR for the entire rocket, except for pyrotechnic elements of the propulsive unit. These elements were continuously purchased separately [1, 2], including propellant grains and igniters for the start (booster) and march (sustainer) motors, as well as deceleration grains for time control the startup of the thrustvector-control system. At the same time, due to high prices and limited service life, they were developed in our country.

All other elements were produced in our government owned company Krušik-Valjevo, specialized for defenseequipment production, which also was performing the final assembling.

The rocket is wire guided and has a range of $3 \mathrm{~km}$. On the back of the missile and its sustainer motor, on the exit of the two nozzles, acts an efficient thrust vector control system with jetavators [3].

Propellant grains had been developed in Bosnia. After the dissolution of Yugoslavia, Military Technical Institute in Belgrade (VTI), in cooperation with our factory "Milan Blagojević"-Lučani, developed a slightly enhanced double base propellant grains for both rocket motors [4], sufficient to achieve the required range of the rocket, with enhanced warheads, also developed in VTI.

A large number of these missiles in the warehouses of our army, along with the need to carry out overhaul of the rocket propellant grains whose reliable service life slowly and continually expires, has led to the idea for the missile modernization, with significantly enhanced warheads and increased range from $3 \mathrm{~km}$ to almost $5 \mathrm{~km}$, using the existing parts of the basic missiles as much as possible.

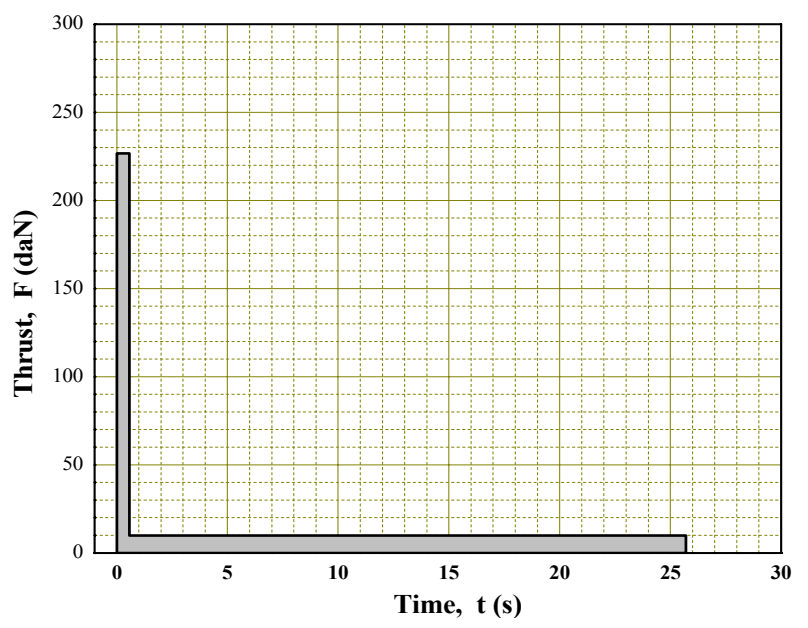

Figure 2. The basic-rocket thrust distribution

\footnotetext{
1) Military Technical Institute (VTI), Ratka Resanovića 1, 11132 Belgrade, SERBIA

Correspondence to: Goran Marjanović; e-mail: milicagoran@gmail.com
} 
Reconstruction of the existing propulsion unit (start motor and sustainer) practically leads to the new design of the rocket, without possibility of sufficient utilization of other existing missile-elements.

The thrust distribution of the basic rocket Maljutka 2 is shown in Fig.2 [2, 4].

This propulsion unit is a textbook example of total-impulse distribution [5-7]. Booster motor is running shortly, producing high thrust and causing the rocket to quickly reach a high speed. The sustainer is running for a relatively long time, about 25 seconds, maintaining the trajectory, and its thrust is used for guidance, overcoming the air resistance and the influence of gravity. Total impulse of the sustainer $(\sim 250$ daNs) is approximately twice the size of the booster impulse.

On the back of the rocket, on the exit of two sustainernozzles, there acts the gas-dynamic thrust vector control system (TVC) with jetavators (Fig.3).

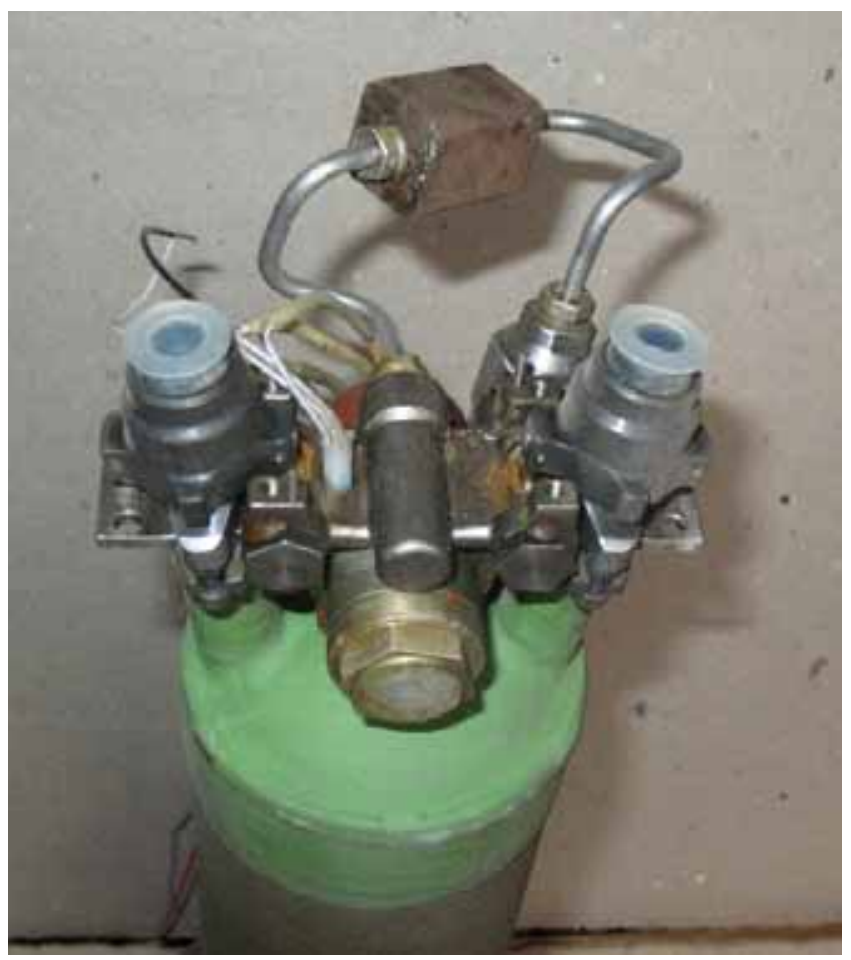

Figure 3. TVC system with a small chamber for measuring the pressure [8]

In the case of reconstruction the existing propulsive unit, the TVC system should be completely changed. Such a procedure would require us to develop a new TVC system, with all the problems and obstacles that this development brings out [3].

Changing the structure of the propulsion unit requires a larger mass of the propellant grains and changing dimensions of the two motors, in proportion to the increased-grains placement and changing the ballistic parameters.

If the speed of the missile is not changed, the bigger range requires the increased operating time of the sustainer rocket motor. It is also possible that the motor-operation time remains unchanged, then the speed of the missile has to be increased, in proportion to the higher range. Proportionally to the increasing range, the mass of motors and the rocket as a whole grows up. If additionally there is also an increased weight of the warhead, the additional weight increase of the propellant grains is needed.

In addition to increasing the range, the requirement was set for an increased weight of the warhead. The basic plan in the design has been defined in order to obtain the minimum possible mass of the rocket. In addition, it was decided not to develop a new TVC system, regardless of the completely different efficiency of the existing system in the rocket with a significantly greater mass.

The rocket flight and its maximum range are influenced by various parameters, as follow:

- The rocket propellant is burning during the flight, resulting in the rocket-mass decrease, and moving the center of gravity $[1,5]$.

- If only the existing propulsion unit is increased, but the existing TVC system is used, it is possible to change only the booster motor, leaving the sustainer unchanged.

- In this case, if both rocket motors start at the same time, at the beginning of the flight, the time of the active flight, which is equal to the burning time of the sustainer, remains the same. Since the range of the rocket is growing up, the average speed of the rocket on a trajectory also has to grow up. This means that the higher speed of the rocket has to be provided only by the booster motor.

- If only the booster motor is changed, which is located on the rear of the rocket, it requires a large increase in the rocket-length for two reasons. First, buster has to be increased because greater rocket-range and the increased mass of the warhead require more energy for transfer to the target, which means more powerful propulsion unit. Second, it is necessary to optimize stand-off, the distance between warhead and the top of the rocket. It means that in the front of the warhead there has to be a part of a missile that has no function. (Fig.4)

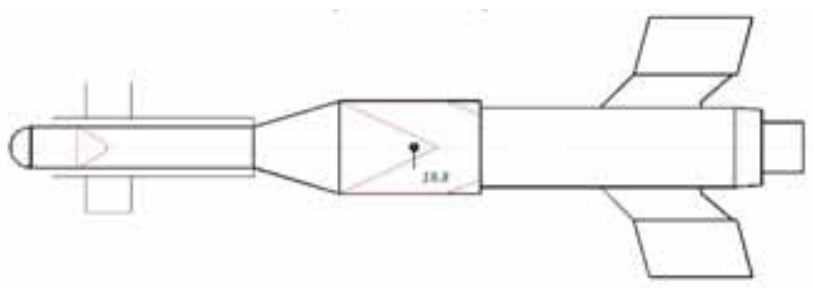

Figure 4. Increased length of the rocket in order to achieve optimum stand-off

- For this reason it is better to fill the front part of the rocket with one of the motors. But in this case it is a completely new motor.

- If a new motor is added in order not to change the existing power unit, average-speed of the rocket can remain approximately the same as for the basic rocket only if the sustainer starts later.

- If the new motors are added, there is a new problem of their positioning in the rocket. Propellant grains of the rocket motors in front of the warhead must have a central channel (Fig.5), to ensure the installation of the central tube for the passage of explosive jet which is formed in the moment of the impact into the target.

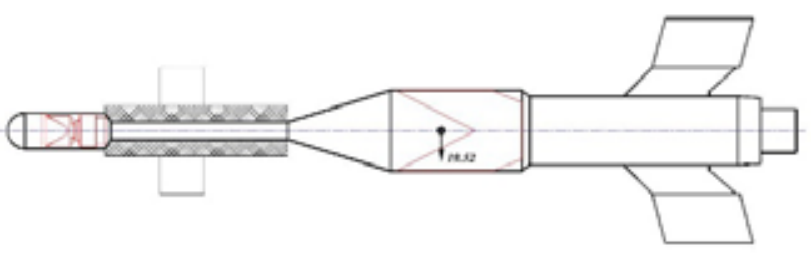

Figure 5. Power unit in front of the main warhead

- In this case, if it is necessary to ensure a long burning time of the motor, there is a technological problem of producing the propellant composition and the grain. Furthermore, a small cross section for the passage of the burning products may be the cause of the occurrence of erosive burning in the ignition phase of the rocket motor. 
- Installing the motors on both sides of warhead is better from the point of view of displacement of the center of gravity.

All the above significant parameters were considered in the preliminary analysis.

\section{An overview of some considered versions of the rocket}

In the beginning of the analysis it was considered a version in which only reconstruction and reinforcement of the basic booster is performed. Ballistic rocket flight was planned, without guidance, until it reaches a distance of about $2 \mathrm{~km}$. After that only the basic sustainer should work, together with the TVC system, to ensure the achievement of the target and missile guidance.

The analysis has shown that an extreme reconstruction of the existing booster motor was needed to achieve an initial distance of $2 \mathrm{~km}$ of ballistic flight and also the total range of $5 \mathrm{~km}$. In this case, however, this would lead to an undesirable increase of the rocket speed to about $300 \mathrm{~m} / \mathrm{s}$, which would significantly increase the air resistance and an uneven rotation of the rocket.

It was assumed that a better result could be achieved if the basic booster is not changed, but if another start motor is added at the front of the rocket (Fig.5). In this way, the two start motors, both ignited at the beginning of the rocket flight, could achieve the required initial distance of $2 \mathrm{~km}$ after about 10 s of the ballistic rocket-flight, with lower rocket speed and better and smoother rotation.

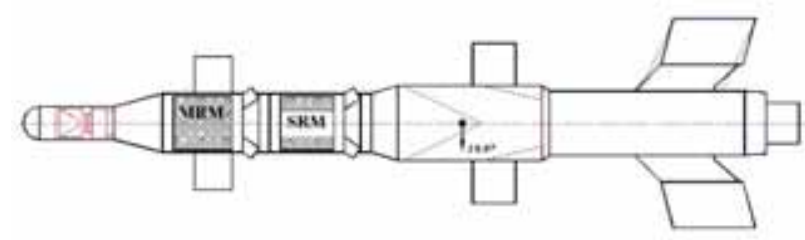

Figure 6. Additional motors in front of the rocket

Various versions were analyzed. At first, it was the additional motor which works longer than the basic booster, but with much lower thrust. Thus, a more peaceful ballistic flight should be achieved in the initial part of the trajectory. In particular, the basic start motor works about $0.6 \mathrm{~s}$ with the thrust over $200 \mathrm{daN}$. The additional motor is planned to work for a few seconds, but with 10 times smaller thrust. One of the analyzed cases was referred to the additional start motor which works over the whole ballistic flight of the rocket. After that, the rocket should be transferred to a horizontal antitank guided trajectory, where the sustainer and TVC system work together up to the target.

However, analysis has shown that it is not enough to add only one motor. Since during the ballistic flight a relatively high speed is achieved, and the air resistance is still very high, over the whole transition regime to the stand-alone mode of the sustainer there are strong variations of the rocket-speed and rotation.

A good solution could be achieved if the additional motor is realized as a two-phase motor or if another motor is also introduced in order to bring stability into the transitional phase, which would reduce the sudden changes of the speed and rotation.

Different cases were analyzed. First, it was the version with both additional motors in front of the warhead (Fig.6). An increased burning time of additional sustainer was needed and it couldn't be provided by radial, but only by end burning.
In that case a compromise was necessary and the solution with central tube for the passage of the explosive jet had to be rejected.

Another case with both additional motors in front of the warhead is shown in Fig.7. There is still the central tube for the passage of explosive jet. In this case, cross-section of the end-burning propellant grain of the sustainer is shaped like a circular ring. Internal and external surfaces have to be inhibited. From the stand point of the explosive-jet passage through the central tube, this is a good solution, but it is very difficult to implement [9].

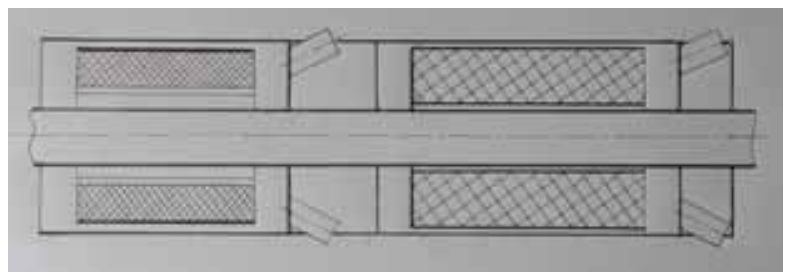

Figure 7. Additional motors in front of the rocket - version 2

In the basic version of rocket Maljutka, both motors (booster and sustainer) begin to work together.

Here, in this analyzed version, the two boosters, the basic and the additional one, as well as the additional sustainer, begin to work simultaneously, at the beginning of the flight. The basic sustainer begins to work later, at the end of the phase of ballistic flight, together with TVC system. Two booster motors work shortly, less than a second, producing high thrust, and providing high speed and approximately $2 \mathrm{~km}$ range of the ballistic trajectory. The task of the additional sustainer motor is to ensure the smooth transition between ballistic and antitank trajectory. It should work less than the basic sustainer, but with slightly higher thrust. Finally, at the end of the flight, the average speed of the rocket is approximately the same as the average speed of the basic rocket Maljutka.

Approximate theoretical thrust diagram for this version is shown in Fig.8.

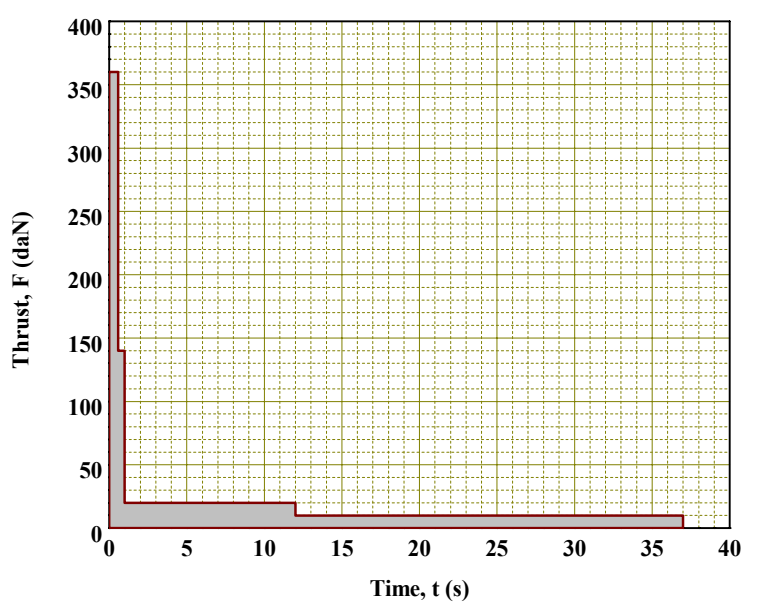

Figure 8. Thrust distribution

In Fig. 9 a version of the rocket with booster in the front of the warhead, and sustainer in the rear, is schematically shown.

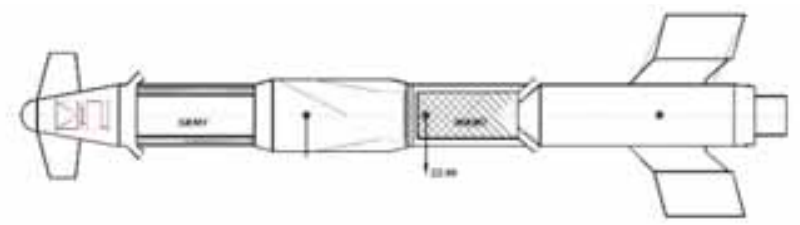

Figure 9. Additional motors on different sides of the warhead 
Several versions have been considered, with different power redistribution between the additional motors in order to find an optimal solution. One of the objectives of this analysis was to use as little as possible rocket propellant in the additional motors, in order to reach the required range of $5 \mathrm{~km}$.

One of the analyzed versions which seemed the most acceptable was named "motor in the motor" (Fig.10). In the central part of the additional propulsion unit there is the sustainer, with end burning. In the outer part there is a booster which burns radially and works very short.

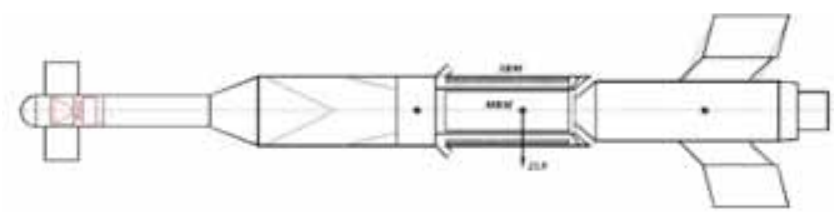

Figure 10. "Motor in the motor" behind the warhead

This design looks quite elegant. Therefore, combustion of the rocket propellant does not cause a large shift of the center of mass of the rocket. A similar solution has been considered in various forms and with different position and shapes of the rocket wings (Fig.11).

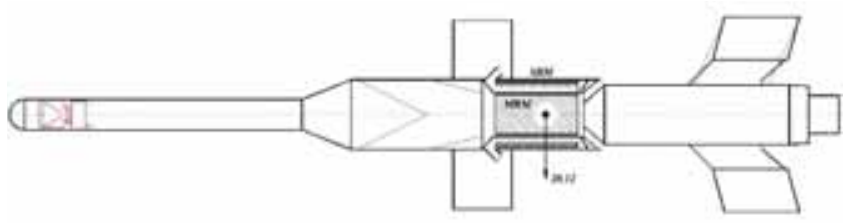

Figure 11. "Motor in the motor" - variant 2

However, this solution is technologically very complex and probably would take a long time to develop it. This solution was not accepted because a relatively fast and reliable additional propulsion unit was required in order to enter the development of the rocket as soon as possible.

In all previous versions, when the two additional motors were considered, it was requested for motors to have the lowest possible mass of rocket propellant. Due to the request to increase the range from 3 to $5 \mathrm{~km}$ (1.67 times), and also to increase the warhead almost 3 times, the theoretical increase of the rocket propellant weight, in comparison to the basic rocket looked not so high (1.7 to 2.0 times). The reason is that in the first part of the trajectory the greater part of the rocket propellant is burned out, while the total mass of the rocket is considerably reduced.

In addition to increasing the range, since the TVC system was not possible to be reconstructed, the task of additional motors was to achieve ballistic trajectory of near $2 \mathrm{~km}$ and to ensure the smooth transition between ballistic and anti-tank trajectory. In this version, the approximate thrust-time distribution of the rocket was similar to that in Fig. 8.

It turned out that such a concept is unacceptable. It is necessary a very precise command guidance and it takes a lot of time to realize the transition from ballistic-flight phase into a semi-automatic mode. In addition, in this version, the minimum operational range is too big because it is $2.5 \mathrm{~km}$ or even more.

In the final step of the analysis, it was considered a version with two additional motors, which have to be ignited on the launch rail at the same time as the basic motors. Total impulses and thrusts distributions of the additional motors were varied to define the best solution. At the end, it was reached a version with the additional motors which have quite similar work regimes like the basic motors. Additional sustainer should have a little less or the same burning time as the basic sustainer, with about 50\% higher thrust, but the guidance has to be realized by TVC system which works only on the basic sustainer.

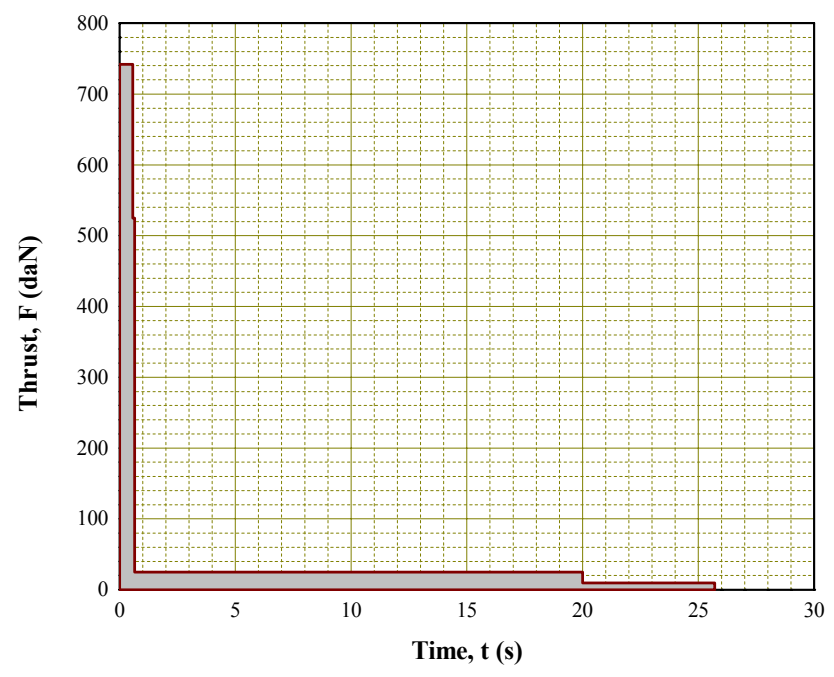

Figure 12. Thrust distribution

Approximate regime of the rocket-thrust is shown in Fig.12. It was planned that the burning time of the additional sustainer should be a little shorter than for the basic sustainer but it was not a strictly limiting parameter.

Finally, in the version which was adopted as the basis for further development of the propulsion unit, the total mass of the rocket propellant is 2.7 times greater than in the basic rocket. The total weight of the rocket is a lot bigger than it was planned at the beginning of the analysis. The following calculation parameters were achieved:

- Minimum operational range is $500-750 \mathrm{~m}$, similar to the basic rocket.

- The change of the rocket-speed is relatively small during the flight. When the boosters finish their work, the rocket achieves a speed of about $170 \mathrm{~m} / \mathrm{s}$.

- The two sustainers continue their work overcoming all environmental resistances and accelerating the rocket to a maximum of $210 \mathrm{~m} / \mathrm{s}$. Since the basic sustainer can't maintain the rocket-speed alone and overcome all resistances, the additional sustainer should work as long as possible, almost like the basic one.

\section{The additional propulsion-unit design}

At the end of the previous analysis, the first technical requirements have been defined for the additional propulsion unit. It is usually the start point in the design of model of a rocket motor.

The additional booster motor should work less than one second, approximately equal to the basic booster, with higher thrust. It should provide, together with the basic start motor, sufficient impulse to launch the rocket from the rail and accelerate it up to $170 \mathrm{~m} / \mathrm{s}$. Total impulse of the additional sustainer also should be significantly higher than the impulse of the basic sustainer. Thus, the total impulse of the additional propulsion unit has to be about 1.7 times greater in comparison to the primary power unit.

The first test models for two additional rocket motors have been defined in cooperation of rocket designers, motor designers and propellant chemists.

The concept of nozzles for additional start motor is selected by the model of the main booster. After the first few iterations, technical requirements for double base propellant were defined so as to achieve a relatively quiet and reliable 
motor work [10], with six nozzles equally positioned around the perimeter of the motor chamber (Fig.13).

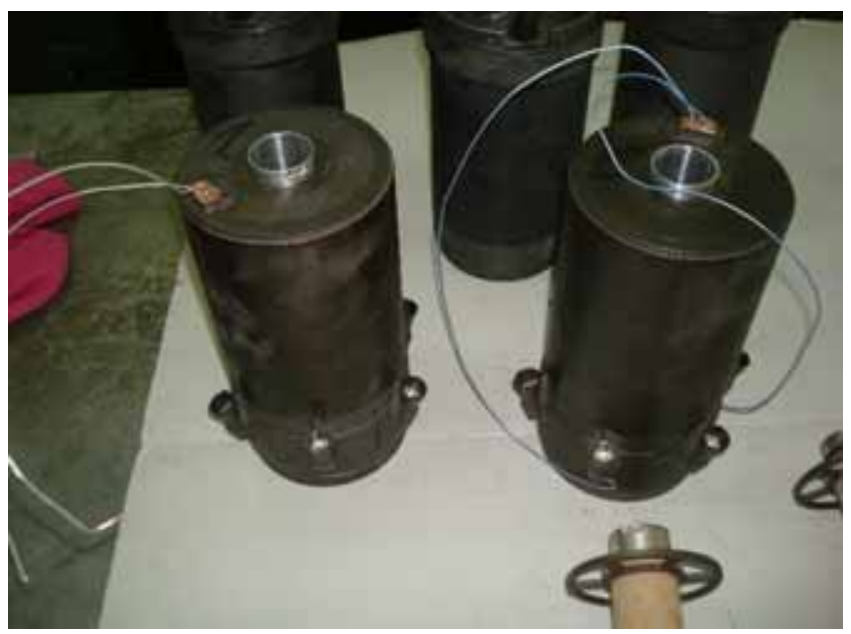

Figure 13. Additional booster motors

It has been defined a relatively simple propellant grain which consists of six internal-external burning tubes [9] positioned around the central tube for the passage of explosive jet (Fig.14).

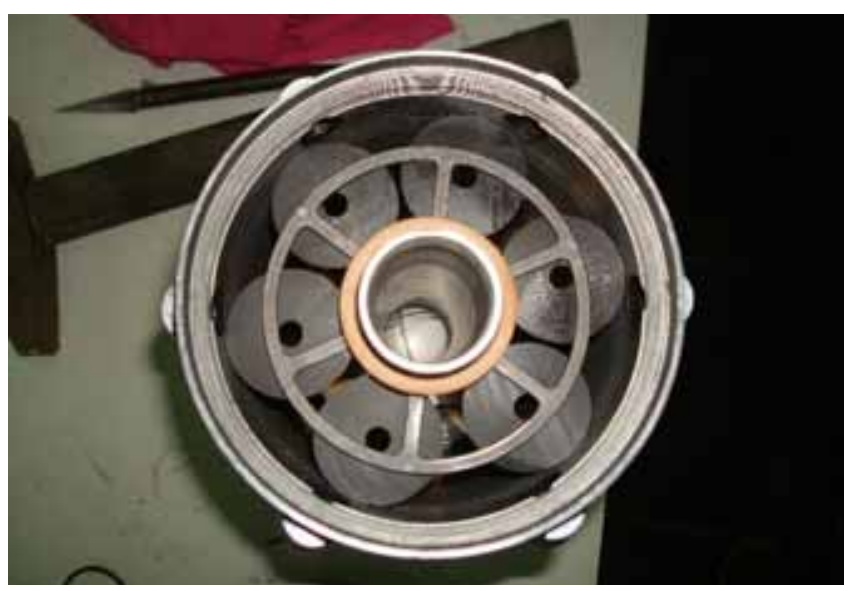

Figure 14. Propellant tubes around the central tube

The first test results of the propellant grain test pieces in the experimental booster motors are shown in Fig.15. The value of total impulse and reliable motor operation are much more important parameters. Therefore, the increase in the initial thrust at the temperature of $+50^{\circ} \mathrm{C}$ is not significant.

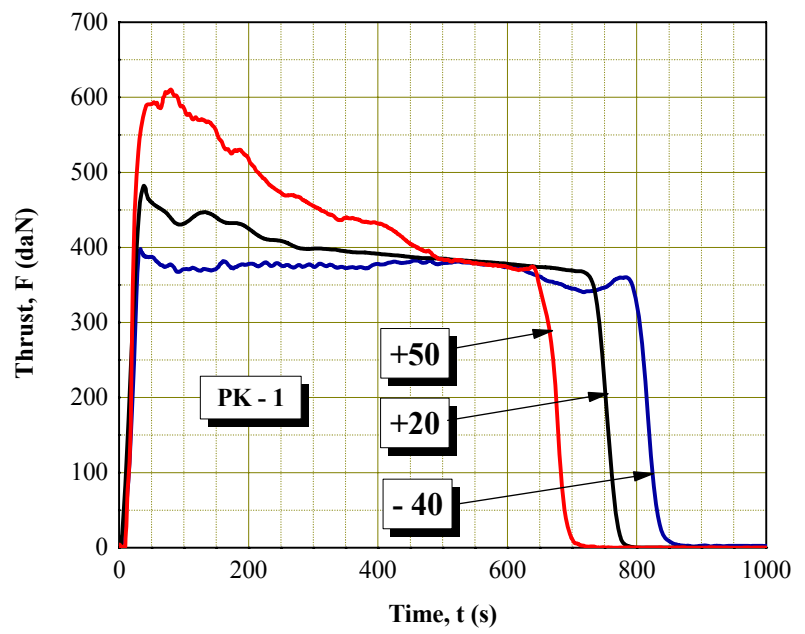

Figure 15. Results of the thrust measurements in the booster test motors
It can be seen that the motor operates stable in all conditions and that thrust does not depend on temperature significantly. There has been realized a low coefficient in the combustion law, which is closely to the appearance of plateau burning. The range of pressures where the plateau effect is present is wide enough to prevent some unexpected pressure picks.

Different problems have arisen in defining the design of the additional sustainer. The long required time of the motor operation caused the type of burning, so the only way was to use an end burning propellant grain, like in the case of the basic sustainer. The requirement for this motor was to achieve relatively high total impulse in comparison to the main sustainer but the same burning time, which meant a significant increase of the propellant mass.

Furthermore, it meant that a higher thrust was needed. In the theory $[5,6,9,10]$, this can be easily achieved by combining the characteristic parameters such as burning surface and nozzle throat diameter, which influences the pressure in the motor. However, the required operating time, the requested mass of propellant and the diameter of the motor chamber leave no great options for defining the working regime in accordance with the possibilities of making the propellant composition.

In order to find a rapid solution to meet deadlines for the start of the rocket development, the following approach was applied:

- Nozzles should hold, with no significant erosion, the quite long motor operation of 20-25 s, which is not easy, and probably would require the purchase of special materials and a long-term development. Therefore, it was tried to select such a regime of motor work, to enable the use of the existing nozzles for the basic sustainer. These nozzles have proven to be very reliable, through the years of practice.

- It was planned, if it is necessary, to perform all the needed corrections by changing the burning surface or the propellant composition.

Detailed calculations have shown that it was possible to achieve good motor design with the four existing nozzles and end-burning propellant grain. On this basis, it was made the end closure of the motor, at first for a test motor and not much later for the flight version (Fig.16).

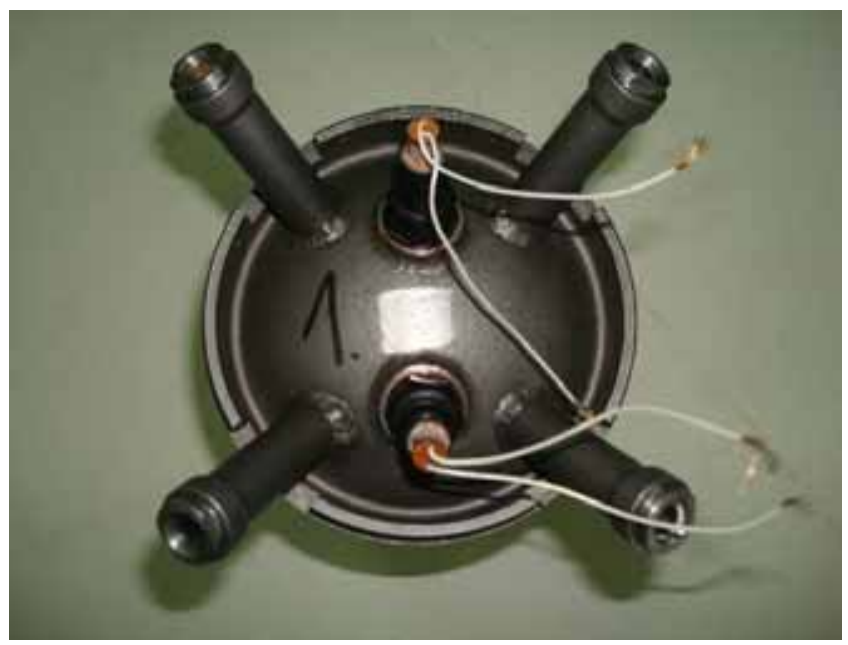

Figure 16. End closure configuration with four nozzles

It was also planned that the additional sustainer has to operate at a regime which should be similar to the operation of the basic sustainer, because there is quite a lot of experience. It referred to technical requirements for the internal-ballistic parameters of the propellant. 
The proposed design solution has required production of a propellant grain whose full cross section was rather large, and there existed a practical problem of producing the grain. The required grain diameter was greater than the maximum diameter that can be prepared by the existing devices for pressing and it was not possible to achieve the desired compression ratio.

However, it has been found a possibility to successfully make the proposed propellant grain. There are existing tools for the production of grains for the sustainer of our guided rocket Bumbar. The diameter of this grain (Fig.17) is also relatively large, but the hollow channel gives the possibility to achieve the desired compression ratio.

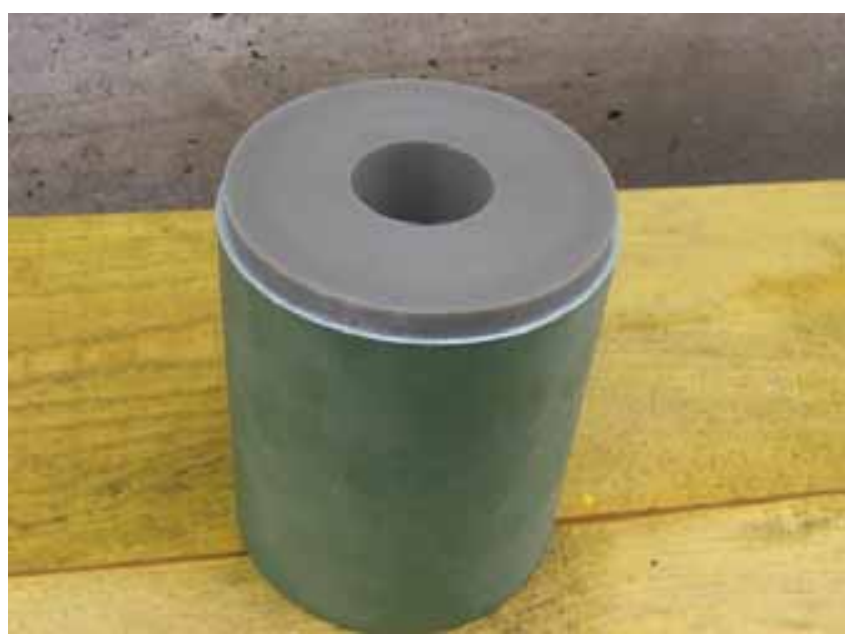

Figure 17. Propellant grain for the rocket motor Bumbar

The central part of the grain (Fig.17) can be made using another existing tool. After completing the two different grains and their mechanical treatment and bonding, the required grain would be successfully made.

There was also a theoretical possibility to make the grain by several pieces of full end-burning cylinders with smaller diameters, packed into the existing caliber, but this combination is quite inefficient and difficult to implement.

In the mean time, the factory for double-base propellants has acquired a larger press for the purpose of its production, and an easy preparation of the required grains was enabled (Fig.18).

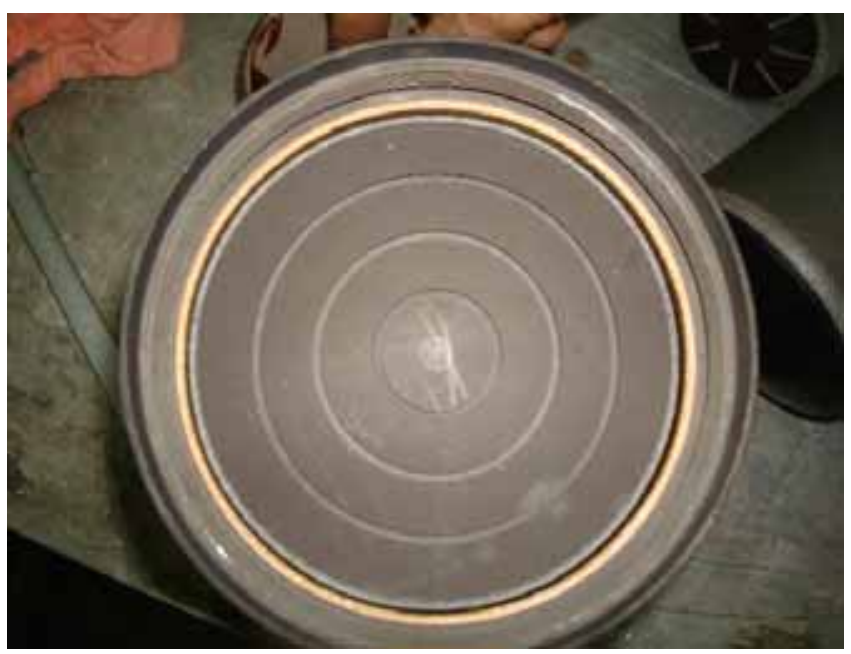

Figure 18. Propellant grain for the additional sustainer

Testing the first models of the propellant grains and the motor as a whole is found to be reliable and good results have been achieved in the complete temperature range of use (Fig.19).

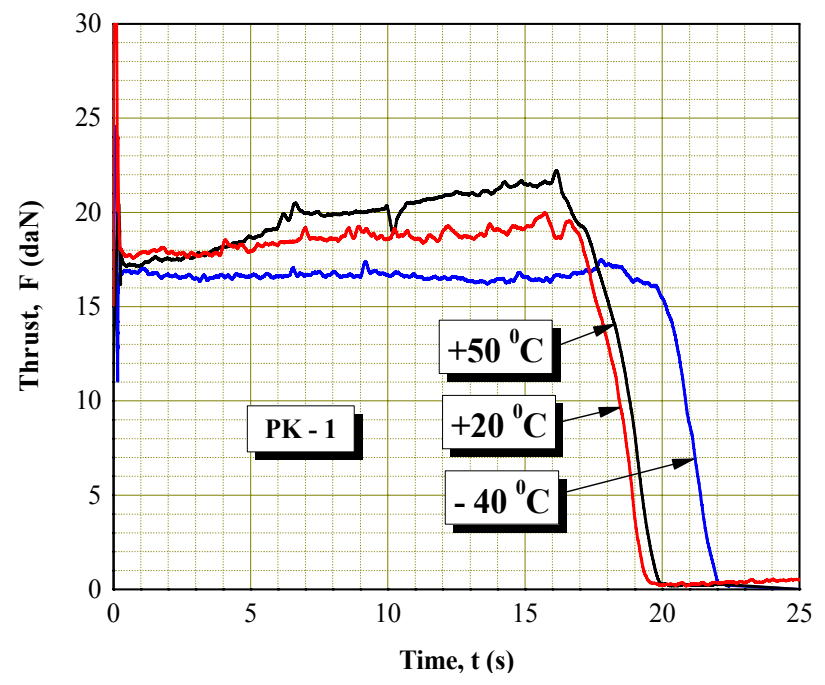

Figure 19. Thrust distributions of the initial sustainer models at the three characteristic temperatures

The thrust dependence on temperature is not too large, which indicates that the width of the plateau in the combustion law is big enough. It can be seen on the diagram an increase in the end-burning surface of the grain, especially at the upper extreme temperature. This phenomenon is known. The end-burning surface during motor operation usually becomes more and more conical.

In the second stage of the development, better results have been achieved because this phenomenon is maximally reduced (Fig.20). Here, the thrust values are lower than in the first stage due to the different technical requirements.

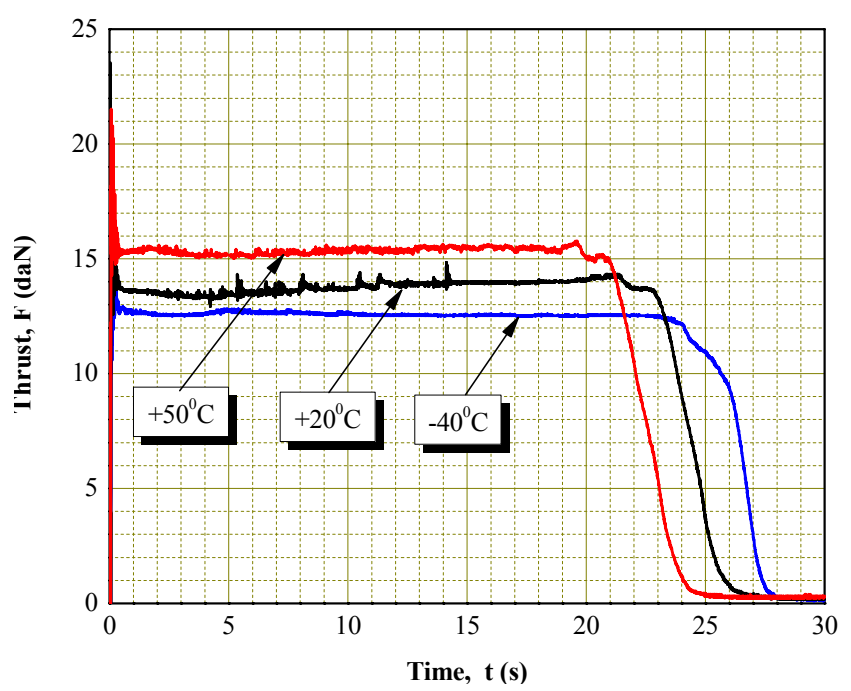

Figure 20. Thrust distribution of the additional sustainer (phase 2)

From the point of view of the required thrust levels, during the development, so far in two occasions some corrections of the propellant composition have been made in order to obtain the required value of the burning rate and to achieve the desired thrust. Technical requirements and thrust levels are usually changed during development of missile systems. It is an integral part of the process.

After successful testing of the propellant grains in the testmotors after production, in the factory of double base propellants, they were also tested in the real flight-motors in MTI, on the test stand in the laboratory for the rocket motor testing (Fig.21).

Propellant grain of the additional sustainer is currently in the third stage of test pieces, which is expected to fully meet the inter-ballistic requirements. 


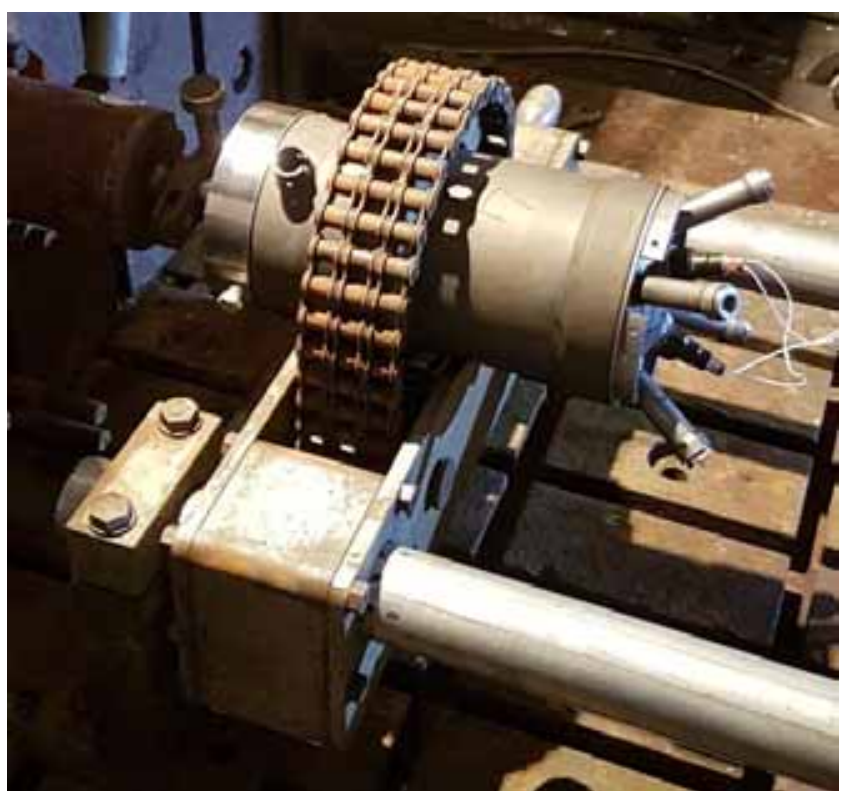

Figure 21. Additional sustainer on the test stand

\section{Conclusion}

During the development of new rocket motors, in the initial tests, some malfunction or even damages usually occur. However, in the first series of static and dynamic tests, two additional motors, in all of their versions (experimental and flight ones), both booster and sustainer, have worked reliably and there were no any incidents.

It can be concluded that the good results have been achieved, from the point of view of the propulsive-group, because the first two stages of the propellant grain test-pieces, as well as two additional motors as a whole, are ready and quite reliable for further flight tests of the missile.

\section{Further development of the propulsive-group}

One of the requirements in the development of additional propulsive-group, simultaneously with the development of the standard double-base propellant grains, is to research and develop a propellant with higher specific impulse. Researching of suitable composition with a certain quantity of nitramines is currently underway.

In addition, during the series of the initial flight tests, it has been recognized that under certain conditions the propulsivegroup is not strong enough to make the rocket reach the desired range of $5 \mathrm{~km}$.

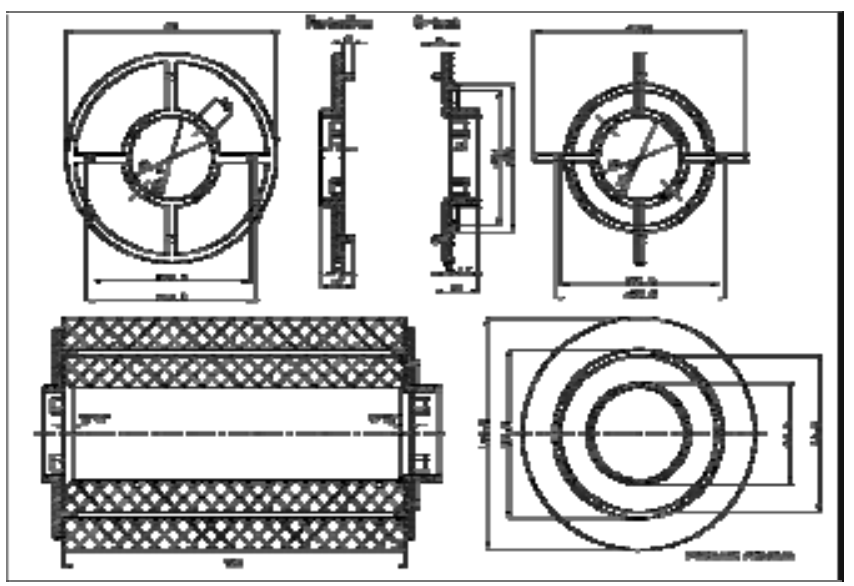

Figure 22. Propellant grain for the new version of the additional booster
New technical requirements for the higher total impulse of the additional booster were defined. The new design of the propellant grain was made (Fig.22), which was supposed to be able to achieve the requirements, because in the same motor case a bigger propellant grain is set. This design has not yet been tested completely and there is a possibility of the occurrence of erosive burning [11].

According to the drawing in Fig.22 the first samples of the new propellant grain were produced (Fig.23), but they are still in the phase of testing and correction the production tools. This propellant grains are popularly named "telescopic grains" because they are defined as two coaxial internal-external burning tubes.

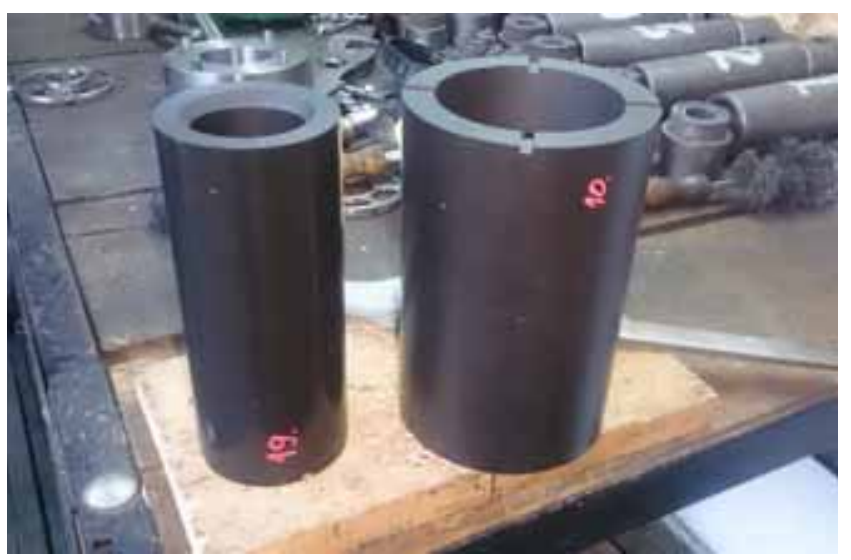

Figure 23. "Telescopic" propellant grains

Fig. 24 presents the comparative thrust curves at standard temperature, for the three different phases of the additional booster motor development. The two lower curves show the thrust distributions of the additional booster in the first two stages of development, and the upper curve was obtained by testing the telescopic grains, which has not yet received their final form.

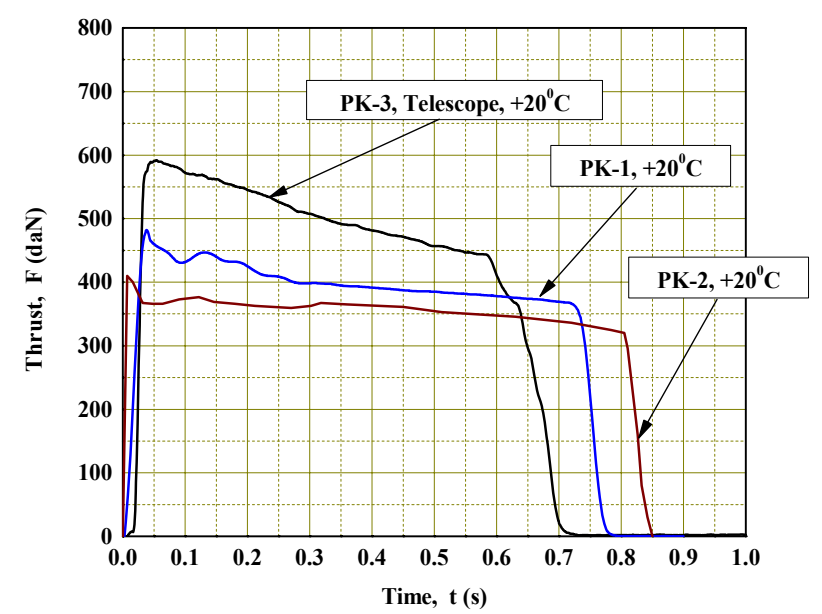

Figure 24. Thrust curves of the additional booster motor in three different phases of development

Then, the next step could be a detailed correction of the whole motor structure, in order to reduce the mass of the rocket and to coordinate with requirements of the system. This does not exclude possible future changes of the technical requirements.

This may be the reasons why the final process of finetuning the propulsion-group parameters could be timeconsuming, but usually it is not an obstacle for the development of other components of the system. 


\section{References}

[1] GLIGORIJEVIĆ,N., etc.: Solid propellant rocket motors - selected topics, Belgrade, MTI\&Mediacenter „Odbrana“,2013, ISBN 978-8681123-63-8, ISBN 978-86-335-0391-04, ID 199479052.

[2] Military Technical Institute's database, internal documentation

[3] ŽIVKOVIĆ,S.: Technical Solutions and Gasdynamic Efficiency of Thrust Vector Control Systems for Rocket Missiles, Military Technical Institute, Belgrade, SERBIA, Scientific Technical Information, ISSN 1820-3418, ISBN 978-86-81123-75-1, 2015, Vol.LII, No.4.

[4] GLIGORIJEVIĆ,N., KOZOMARA,S.: Maljutka 2 - sustainer rocket motor, Propellant grain acceptance tests, Technical Rept., VTI-03-010052, Dec. 2011

[5] BARRERE,M., JAUMOTTE,A., VEUBEKE,B.F., VANDENKERCKHOVE,J.: Rocket Propulsion, Elsevier Publishing Company, Amsterdam-London-New York, 1960.

[6] WIMPRESS,R.N.: Internal Balistics of Solid-Fuel Rocket Motors, McGraw-Hill Book Company, New York-Toronto-London, 1950.
[7] SUTTON,G.P., BIBLARZ,O.: Rocket Propulsion Elements, Eighth edition. John Wiley \& Sons inc., 2010, ISBN 978-0-470-08024-5.

[8] GLIGORIJEVIĆ,N., SUBOTIĆ,S.: Captive-Fired Testing of Solid Propellant Rocket Motors, Military Technical Institute, Belgrade, SERBIA, Scientific Technical Information, ISSN 1820-0206, ISBN 978-86-81123,79-9, 2016, Vol.LIII, No.3.

[9] NASA SP-8076, Solid propellant grain design and internal ballistics,NASA Space Vehicle Design Criteria, 1972.

[10] NASA SP-8039, May 1971, Solid Rocket Motor Performance Analysis and Prediction, NASA Space Vehicle Design Criteria.

[11] BOULAHLIB,M.A., TORCHE,R., ŽIVKOVIĆ,S., SUBOTIĆ,S., GLIGORIJEVIĆ,N.: An example of a successful erosive burning reduction in a small rocket motor, $6^{\text {th }}$ International Scientific Conference OTEH 2014, 09-10. October 2014, Belgrade, SERBIA, ISBN 978-86-81123-71-3, pp.380-387.

Received: 19.04 .2018 . Accepted: 12.10.2018.

\title{
Stanje razvoja pogonske grupe pojačane protivoklopne rakete
}

\begin{abstract}
Osnovna pogonska grupa protiv-oklopne vođene rakete je pojačana dodatnom pogonskom grupom da bi se obezbedilo traženo povećanje dometa. Konačni koncept pogona je usvojen nakon analize nekoliko predloženih rešenja. Trenutno su u razvoju dva dodatna motora. Dobijeni su prvi rezultati ispitivanja motora i početna rešenja se koriguju izmenom sastava pogonske materije i dimenzija i oblika pogonskih punjenja. Prikazan je pregled uobičajene procedure konstrukcije motora u cilju ostvarenja potrebnog rešenja pogona rakete.
\end{abstract}

Ključne reči: PO raketa, raketni motor, pogonska grupa, startni motor, marš motor, pogonsko punjenje, potisak, pritisak, domet.

\section{Состояние развития приводной группы усиленной противотанковой ракеты}

\begin{abstract}
Основная приводная группа противотанковой ракеты, управляемой против столкновения, была усилена дополнительной приводной группой для обеспечения необходимого увеличения дальности. Окончательная концепция привода была принята после анализа нескольких предложенных решений. Два дополнительных двигателя сейчас находятся в стадии разработки. Первые результаты испытаний двигателя были получены, и первоначальные решения были скорректированы путём изменения состава топлива, а также и размеров и форм заряда двигателя. Обзор традиционного процесса конструкции двигателя представлен для того, чтобы достичь требуемого решения тяги привода ракеты.
\end{abstract}

Ключевые слова: противотанковая (противокорабельная) ракета, ракетный двигатель, приводная группа, пусковой двигатель, марш-двигатель, заряд двигателя, тяга, давление, дальность.

\section{Etat de développement du groupe propulsif chez la fusée antichar}

\begin{abstract}
Le groupe propulsif basique chez la fusée antichar guidée a été renforcé par un groupe propulsif supplémentaire dans le but d'assurer l'augmentation demandée de la portée. Le concept final de la propulsion a été adopté après l'analyse de plusieurs solutions proposées. En ce moment deux moteurs additionnels sont en voie de développement. On a obtenu les premiers résultats de l'examen du moteur et les solutions initiales sont corrigées par la modification de la composition de matière propulsive ainsi que des dimensions et des formes des charges propulsives. On a présenté le tableau de la procédure habituelle pour la construction du moteur dans le but de la réalisation de la solution pour la propulsion de fusée.
\end{abstract}

Mots clés: fusée antichar, moteur à fusée, groupe propulsif, moteur de démarrage, moteur de marche, charge, poussée, pression, portée. 